\title{
STUDY OF SURFACE WATER QUALITY AND ITS TREATMENT USING BIO COAGULANTS
}

\author{
Chindu Mohan ${ }^{1}$, Swati Shasi ${ }^{2}$, Shivakumar ${ }^{3}$, Shakthivel $\mathbf{P}^{4}$, Sri Sanjith ${ }^{5}$ \\ ${ }^{1}$ Assistant professor, School of Civil Engineering, REVA University, Bangalore, India \\ ${ }^{2}$ Student, Reva ITM, Bangalore, India \\ ${ }^{3}$ Student, Reva ITM, Bangalore, India \\ ${ }^{4}$ Student, Reva ITM, Bangalore, India \\ ${ }^{5}$ Student, Reva ITM, Bangalore, India
}

\begin{abstract}
This study aims in understanding the physical, chemical and biological conditions of Kattigenahalli Lake. This Lake is situated in Kattigenahalli, Yelahanka. This is not being used by residents due to unknown reasons. This work aims in treating the lake water using organic purification which consists of three bio coagulants, which are Moringa oleifera, Tamarind seeds and activated charcoal using rice husk. These were used as locally available natural coagulants in this study to reduce turbidity and other parameters.

Optimum dosage of Moringa oleifera seeds Powder, Tamarind seed powder and activated charcoal of rice husk was found to be $0.4 \mathrm{~g} / \mathrm{l}, \mathrm{g} / \mathrm{l}$ and $3.5 \mathrm{~g} / \mathrm{l}$ respectively. The percentage reduction in turbidity after treating the lake water with Moringa Oleifera Seeds Powder, Tamarind Seeds Powder and Activated Charcoal from rice husk was found to be $24.07 \%, 65.82 \%$ and $78.14 \%$ respectively. Among the three Biocoagulants used, activated charcoal was found to be the best as it reduced 78.14\% of turbidity of the lake water.
\end{abstract}

Keywords—lake, surface water, bio coagulants, Moringa oleifera, rice husk, tamarind seeds

\section{INTRODUCTION}

Healthy Lakes are needed to maintain the ecological balance of the nature and they augment our bio diversity. Lakes store huge amount of water and helps during droughts and shortages as well as acts a sink during floods. Lakes also help in groundwater recharge, and also influence the water quality of downstream watercourses.

Most of the major surface water bodies in Bangalore have been heavily polluted. This led to over exploitation of existing groundwater supplies. Inconsiderate disposal of solid and hazardous waste has polluted these aquifers to the extent that they are not able to meet the drinking water standards. Over pumping of groundwater has resulted in lowering of the groundwater level in most parts of Bangalore.

Yelahanka is a small sub urban place of Bangalore in the state of Karnataka which is now a part of the Bruhat Bangalore Mahanagara Palike (BBMP). Yelahanka has several lakes and Kattigenahalli Lake is situated at a longitude of 37'30' and latitude of 7'30. Construction work is going on in the lake premises by the BBMP authority to make the lake as a point for social activities. ". This lake was also found to be polluted due to sewage discharge.

Coagulation of water using alum as the coagulant is a regular practice in all water works since long time. Coagulation helps in removing the colloidal particles as well as pathogens that are attached to the particles. However, the cost of these chemicals and its side effects in long run has caused to consider the natural coagulants as an encouraging alternative. In the present study, Moringa Oleifera, tamarind seeds and activated charcoal made from rice husk was selected as coagulants. Earlier studies had shown that most of these bio-coagulants can reduce turbidity better than alum. Tamarind seeds are also are said to reduce turbidity and fluoride content. Activated charcoal derived from rice husk is found to be an excellent medium to remove turbidity, colour and few heavy metals.

\section{METHODOLOGY}

A. Collection of samples: The lake water was collected in thoroughly washed, five litre capacity plastic cans during morning time (8:30-9:30) on the sampling days. Water samples were collected near the bank of the lake as well as from the lake interiors to maintain an average and a uniform quality for the sample.

B. Preservation of the samples: The samples collected were preserved at optimum temperature of about $4^{0} \mathrm{C}$.

C. Analysis: The samples collected were analysed to find out the physical, chemical and biological contents, based on the analysis the samples were treated by using organic methods as given below; 
D. Moringa Oleifera Seeds Powder (MOSP): Moringa Oleifera Seeds which was ripened and not edible was preferred for the study. It was collected and deseeded and then dried properly in sunlight until all the moisture was evaporated. The dry seeds were then ground to get fine powder. The MOSP was sieved and used for the analysis.

E. Tamarind Seed Powder (TSP): Tamarind seed used in this study was first soaked in water to remove the pulp; it was washed well with tap water. Further the tamarind seeds were properly dried in the sunlight. The seeds were first crushed in motar and pestle and the outer covering was removed as much possible, further it was powdered finely and sieved under 150 micron and was used for the test.

F. Activated charcoal from Rice Husk (ACRH): Rice Husk was obtained from local rice mills. In the first step, (Carbonization) 15 gram of Rice Husk was heated gradually at a temperature rate $\left(250-300^{\circ} \mathrm{C}\right)$ for fifteen minutes in a muffle furnace. It was activated at $105{ }^{0} \mathrm{C}$ for 20 mins. The product was cooled giving desired pure adsorbent.

G. Jar test: The analysis of optimum dosage of coagulant was conducted in jar test apparatus. Jar test was conducted with varying quantities of MOSP, TSP and $\mathrm{ACRH}$ at uniform $\mathrm{pH}$ and temperature.

\section{RESULTS AND DISCUSSIONS}

\subsection{Initial Water Quality of the Lake}

The initial analysis of lake water sample had given the following results:

Table 1: Initial Water Quality Parameters

\begin{tabular}{|l|l|}
\hline Parameters & Average values \\
\hline Turbidity (NTU) & 18 \\
\hline $\mathrm{pH}$ & 8.06 \\
\hline Colour & Not agreeable \\
\hline Odour & Objectionable \\
\hline Total Hardness $\left(\mathrm{mg} / \mathrm{l} \mathrm{as} \mathrm{CaCO}_{3}\right)$ & 189.8 \\
\hline Calcium Hardness $\left(\mathrm{mg} / \mathrm{l} \mathrm{as} \mathrm{CaCO}_{3}\right)$ & 64 \\
\hline $\begin{array}{l}\text { Magnesium Hardness }(\mathrm{mg} / \mathrm{l} \text { as } \\
\left.\mathrm{CaCO}_{3}\right)\end{array}$ & 125.8 \\
\hline DO content $(\mathrm{mg} / \mathrm{l})$ & 8.1 \\
\hline Chloride content (mg/l) & 92.5 \\
\hline Total Coliforms (MPN/100 ml) & 161 \\
\hline
\end{tabular}

Most of the physical and chemical parameters were well within the permissible limits prescribed by Indian Standards, but colour and odour were disagreeable. The sample had high content of total Coliforms also. Turbidity of the lake water was 18 NTU. As per the Indian Standards, 5-10 NTU is acceptable for drinking water. Therefore the lake water required purification before domestic usage.

\subsection{Jar Test to Find the Optimum Dosage}

\subsubsection{Tamarind Seed Powder (TSP)}

Jar test was conducted to find the optimum dosage of tamarind seed powder by varying the dosages. The optimum dosage was found to be $1 \mathrm{~g} / \mathrm{l}$ which was efficient in removing $65.82 \%$ of turbidity. The results are tabulated below:

Table 2: Optimum dosage of TSP

\begin{tabular}{|l|l|l|l|l|}
\hline $\begin{array}{l}\text { Tri } \\
\text { al } \\
\text { no. }\end{array}$ & $\begin{array}{l}\text { Dosag } \\
\text { e } \\
\text { g/l }\end{array}$ & $\begin{array}{l}\text { Initial } \\
\text { turbidity } \\
\text { (NTU) }\end{array}$ & $\begin{array}{l}\text { Final } \\
\text { turbidity } \\
\text { (NTU) }\end{array}$ & $\begin{array}{l}\text { \% reduction in } \\
\text { turbidity }\end{array}$ \\
\hline 1 & 0.2 & 16 & 10 & $37.5 \%$ \\
\hline 2 & 0.4 & 16 & 10 & $37.5 \%$ \\
\hline 3 & 0.6 & 16 & 12 & $25 \%$ \\
\hline 4 & 0.8 & 16 & 12 & $25 \%$ \\
\hline 5 & 1 & 19.9 & 6.8 & $65.82 \%$ \\
\hline 6 & 2 & 19.9 & 7.6 & $61.8 \%$ \\
\hline 7 & 3 & 19.9 & 8.6 & $56.78 \%$ \\
\hline 8 & 4 & 19.9 & 8.2 & $58.79 \%$ \\
\hline
\end{tabular}

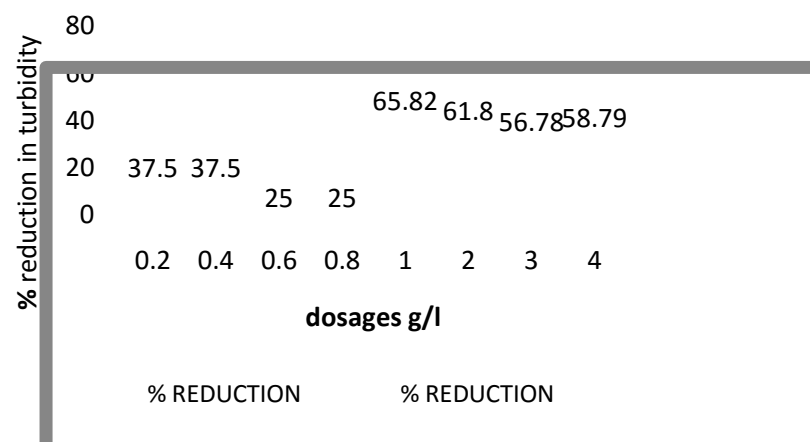

Fig 1: Percentage reduction in Turbidity of sample versus TSP dosage

\subsubsection{Moringa Oleifera Seed Powder (MOSP)}

Jar test was conducted to find the optimum dosage of MOSP by varying the dosages. The optimum dosage was found to be $2 \mathrm{~g} / \mathrm{l}$ which was efficient in removing $24.07 \%$. The results are tabulated below:

Table 3: Optimum dosage of MOSP

\begin{tabular}{|l|l|l|l|l|}
\hline $\begin{array}{l}\text { Trial } \\
\text { no. }\end{array}$ & $\begin{array}{l}\text { Dosage } \\
\text { g/l }\end{array}$ & $\begin{array}{l}\text { Initial } \\
\text { turbidity }\end{array}$ & $\begin{array}{l}\text { Final } \\
\text { turbidity }\end{array}$ & $\begin{array}{l}\% \\
\text { reduction }\end{array}$ \\
\hline 1 & 2 & 16.2 & 12.3 & $24.07 \%$ \\
\hline 2 & 4 & 16.2 & 13.4 & $17.28 \%$ \\
\hline 3 & 6 & 16.2 & 27.3 & - \\
\hline 4 & 8 & 16.2 & 58 & - \\
\hline
\end{tabular}




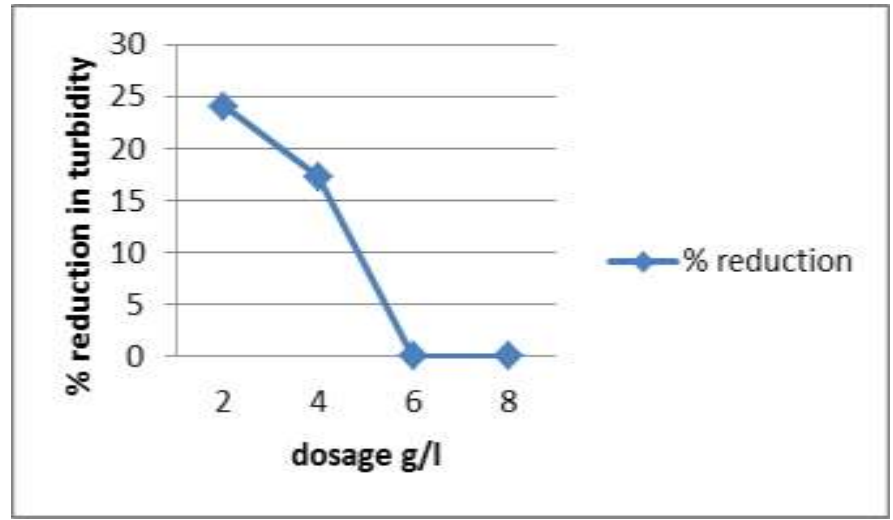

Fig 2: Percentage reduction in Turbidity of sample versus MOSP dosage

\subsubsection{Activated Charcoal using Rice Husk (ACRH)}

Jar test was conducted to find the optimum dosage of activated charcoal from rice husk by varying the dosages. The optimum dosage was found to be $3.5 \mathrm{~g} / \mathrm{l}$ which was efficient in removing $78.14 \%$ of turbidity. The results are tabulated below:

Table 4: Optimum dosage of ACRH

\begin{tabular}{|l|l|l|l|l|}
\hline $\begin{array}{l}\text { Trial } \\
\text { no. }\end{array}$ & $\begin{array}{l}\text { Dosage } \\
\text { g/l }\end{array}$ & $\begin{array}{l}\text { Initial } \\
\text { turbidity }\end{array}$ & $\begin{array}{l}\text { Final } \\
\text { turbidity }\end{array}$ & $\begin{array}{l}\text { \% } \\
\text { reduction }\end{array}$ \\
\hline 1 & 1 & 16 & 6.2 & $61.25 \%$ \\
\hline 2 & 2 & 16 & 4.9 & $69.37 \%$ \\
\hline 3 & 3 & 16 & 6.2 & $61.25 \%$ \\
\hline 4 & 3.5 & 16 & 3.5 & $78.14 \%$ \\
\hline
\end{tabular}

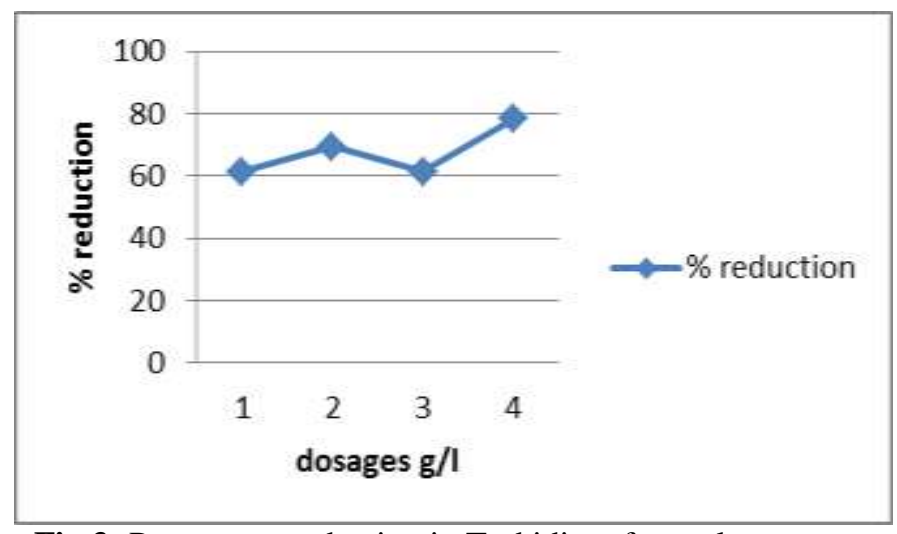

Fig 3: Percentage reduction in Turbidity of sample versus ACRH dosage

\subsection{Comparison between all the Three}

\section{Biocoagulants}

The three Biocoagulants used for the study, viz MOSP, TSP and ACRH was found to be good coagulants as the turbidity of sample was reduced considerably. But ACRH was the best among the three, as there was a turbidity reduction of $78.14 \%$.

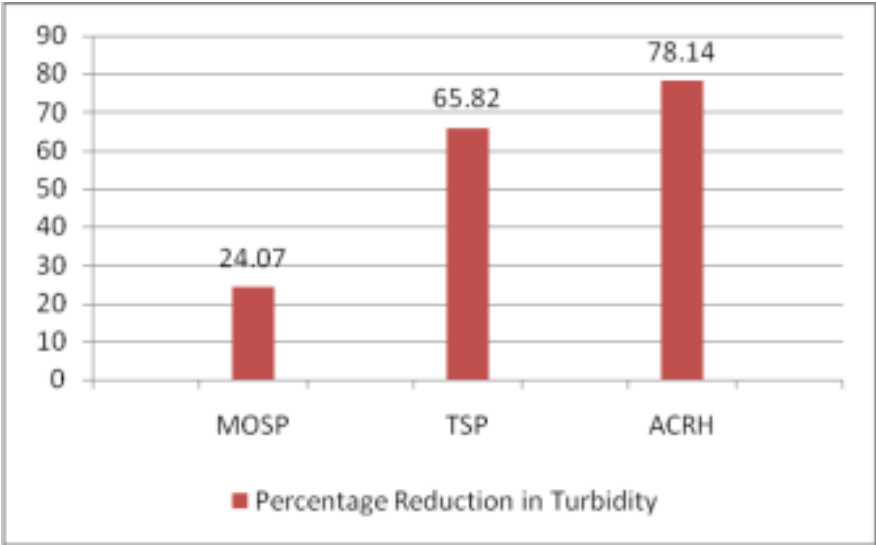

Fig 4: Comparison between MOSP, TSP and ACRH in reduction of turbidity

\section{CONCLUSION}

By conduction of jar test for the bio coagulants such as Moringa oliefera, tamarind seeds and activated charcoal using rice husk, it is clearly seen that activated charcoal is a better coagulant in removing turbidity. It has extensively developed internal pore structure. Due to activation, internal pore network is created and thus carbon gets its unique characteristics leading to high surface area, porosity and greater strength.

\section{ACKNOWLEDGMENTS}

This project was approved by KSCST. We really thank them for considering it and sanctioning KSCST fund for carrying out this project successfully.

\section{REFERENCES}

[1] Shaasana Parishodhane by Dr. M...G. Manjunaatha, Dept. of Kannada, Mysuru University

[2] Dr. Syed Eqbal Hasan, Water and Ecological Balance, Islamic Research Foundation International, Inc.

[3] T.Phani Madhavi1, R. RajKumar, International Journal of ChemTech Research International Journal of ChemTech Research

[4] Smrutirekha Das, characterization of activated carbon of coconut shell, rice husk and karanja oil cake, Department of Chemical Engineering National Institute of Technology Rourkela-769008 2014

[5] Mangale S. M., Chonde S. G., Jadhav A. S., and Raut P. D. Study of Moringa Oleifera seed as natural Absorbent and Antimicrobial agent for River water treatment. Nat. Prod. Plant Resource, 2012, 2 (1):89100 .

[6] K. A. Yongabi, Biocoagulants for Water and Waste Water Purification, International Review of Chemical Engineering, Vol. 2 N. 3 May 2010. 